\title{
Erratum to: Screening for new sources of resistance to Clavibacter michiganensis subsp. michiganensis $(\mathrm{Cmm})$ in tomato
}

Yusuf Sen $\cdot$ Feng Zhu $\cdot$ Henri Vandenbroucke $\cdot$ Jan van der Wolf • Richard G. F. Visser •

A. W. van Heusden

Published online: 6 November 2012

(C) Springer Science+Business Media Dordrecht 2012

\section{Erratum to: Euphytica \\ DOI 10.1007/s10681-012-0802-1}

Due to an unfortunate turn of events, the first- and surname of the second author was transposed. The correct representation of the authors and their affiliations are listed above and below and should be treated as definitive by the reader.

The online version of the original article can be found under doi:10.1007/s10681-012-0802-1.

Y. Sen $(\bowtie) \cdot$ F. Zhu $\cdot$ H. Vandenbroucke

R. G. F. Visser - A. W. van Heusden

Department of Plant Breeding, Wageningen University

and Research Centre, P.O. Box 386,

6700 AJ Wageningen, The Netherlands

e-mail: yusuf.sen@wur.nl

A. W. van Heusden

e-mail: sjaak.vanheusden@wur.nl

Y. Sen

Graduate School Experimental Plant Sciences,

Wageningen, The Netherlands

J. van der Wolf

Plant Research International Biointeractions and Plant

Health, Droevendaalsesteeg 1, 6708 PB Wageningen,

The Netherlands 